\title{
TWO SPECIES OF THE GENUS IBACUS (CRUSTACEA DECAPODA: REPTANTIA) FROM JAPAN
}

$\operatorname{AUTHOR}(\mathrm{S})$ :

Harada, Eiji; Holthuis, L.B.

\section{CITATION:}

Harada, Eiji ...[et al]. TWO SPECIES OF THE GENUS IBACUS (CRUSTACEA DECAPODA : REPTANTIA) FROM JAPAN. PUBLICATIONS OF THE SETO MARINE BIOLOGICAL LABORATORY 1965, 13(1): 23-34

ISSUE DATE:

1965-06-30

URL:

http://hdl.handle.net/2433/175395

RIGHT: 


\title{
TWO SPECIES OF THE GENUS IBACUS (CRUSTACEA DECAPODA : REPTANTIA) FROM JAPAN ${ }^{1)}$
}

\author{
EIJI HARADA \\ Biological Laboratory, Yoshida College, Kyoto University \\ and \\ L. B. HOLTHUIS \\ Rijksmuseum van Natuurlijke Historie, Leiden, Netherlands
}

With Plate VII and 3 Text-figures

Eversince the publication of DE HAAN's (1833-1850) monograph, Ibacus ciliatus (von Siebold) has been generally regarded to be the only member of the genus Ibacus inhabiting the seas around Japan. In fact, this species is abundant in and characteristic for the level sandy and muddy bottoms of the continental shelf along the coasts of Kii Peninsula (UTinomi and Harada, 1957; HARAdA, 1958) and southern Japan. As it has been stated by BaLss (1914, p. $80 ; 1924$, p. 60 ) and by EkMAN $(1953$, p. 23), this species is considered to be endemic to the southern or subtropical Japanese region.

However, recently Kuво (1960) referred to another species of Ibacus as inhabiting Japanese waters, when he gave an illustrated description of Ibacus ciliatus, saying that "there is Ohba-utiwaebi, Ibacus incisus, which is a relative of Utiwaebi, Ibacus ciliatus." Supposedly this remark by KuBo is based on a specimen in the collection of the Seto Marine Biological Laboratory, which has been labelled by him as Ibacus incisus (PÉRON). This specimen was reexamined by HARADA, who also studied an additional specimen preserved in the collection of the Seto Marine Biological Laboratory and two live specimens trawled on the continental shelf off Minabe at a depth of approximately 100 metres. All these specimens indeed showed a remarkable resemblance to Ibacus peronii LEACH (of which Ibacus incisus is a synonym), and differed considerably from I. ciliatus. Later, in 1962, without a great hope of success, HARADA sent out requests to fishermen to collect specimens of the genus if they could find any in commercial catches. Immediately three specimens

1) Contributions from the Seto Marine Biological Laboratory, No. 434.

Publ. Seto Mar. Biol. Lab., XIII (1), 23-34, $1965 . \quad$ (Article 2) 
came from Mr. K. NaKano of Tamagawa, Yamaguchi Prefecture. They were all collected off Masuda in the Japan Sea and were found not to be Ibacus ciliatus. A few specimens have been collected further off Kamaye in the Bungo Strait, as well as off Minabe. Two of these specimens were sent to Holthuis, who at the moment is preparing a world-wide revision of the family Scyllaridae. The Japanese specimens proved to belong to Ibacus novemdentatus Gibbes and not to Ibacus peronii Leach.

In the present paper brief descriptions and figures of the two Japanese species of Ibacus are given to help further studies of the genus as well as of their larvae, and their geographical distributions are discussed (Text-fig. 1).

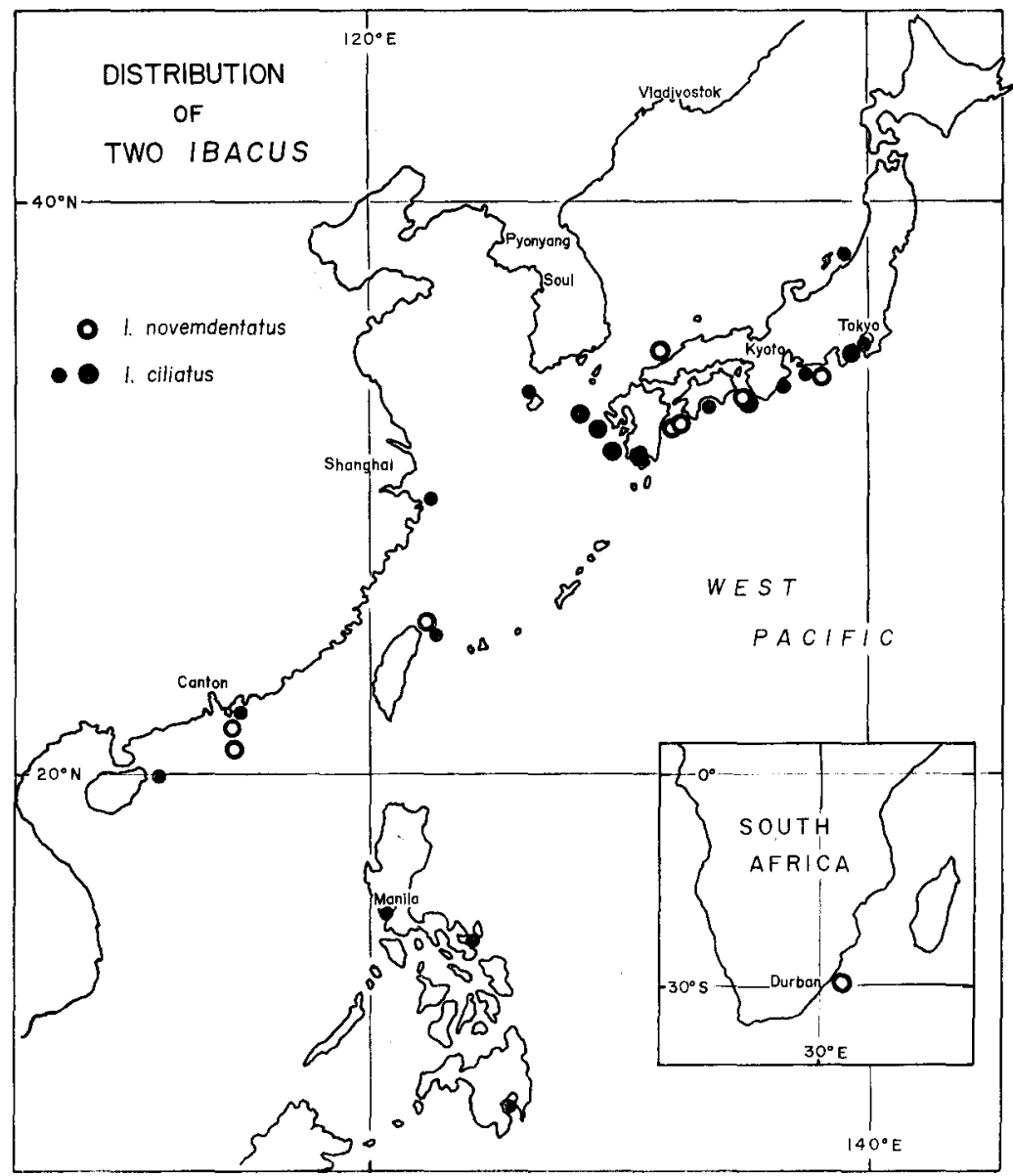

Text-fig. 1. Distribution of Ibacus ciliatus (solid circle) and Ibacus novemdentatus (light circle), based on the materials at our disposal and in various museums cited elsewhere, as well as on the records of collection published by various authors. Larger solid circles mean where the animal is fished in quantity or has been caught frequently. 
Our sincere thanks are due to Professor H. UTinomi and Professor I. KuBo for kindly reading the manuscript and giving us helpful criticisms. We are also indebted to $\mathrm{Mr}$. Ch. Araga, Mr. S. Nishimura and Mr. C. K. Ko for providing us materials and informations.

\section{Ibacus ciliatus (VON SIEBOLD)}

(Japanese name: Utiwaebi)

(Text-fig. 2 ; Plate VII, figs. 3-4)

\section{Scyllarus Ciliatus}

von Siebold, 1824, Spicil. Faun. Japon., p. 15.

Scyllarus (Ibacus) ciliatus

DE HAAN, 1841, Fauna Japon. Crust., p. 153.

Ibacus ciliatus

DE HAAN, 1841, Fauna Japon. Crust., Pl. 36/37, fig. 2.

OrTMANN, 1891, Zool. Jb. Syst., Vol. 6, p. 45.

Doflein, 1902, Abh. Bayer. Akad. Wiss., Vol. 21, p. 643.

ParisI, 1917, Atti Soc. Ital. Sci. Nat., Vol. 56, p. 12.

YokoyA, 1933, Journ. Coll. Agric. Tokyo Imp. Univ., Vol. 12, p. 48.

HoLthuls, 1946, Temminckia, Vol. 7, p. 101.

NAKAZAWA (\& KUBO), 1947, Illustr. Encycl. Fauna Japan, rev. ed., p. 759, fig. 2189.

Utinomi, 1956, Coloured Illustr. Sea Shore Anim. Japan, p. 62.

Harada, 1958, Publ. Seto Mar. Biol. Lab., Vol. 7, p. 173, text-figs. 1-2, Pls. 9-11.

Kubo, 1960, Encycl. Zool, Illustr. Colours, Vol. 4, p. 98, Pl. 49, fig. 8.

Ibaccus (sic) ciliatus

Balss, 1914, Abh. Bayer. Akad. Wiss., Suppl. Vol. 2, Pt. 10, p. 80, fig. 44.

Maki \& Tsuchiya, 1923, Rep. Dept. Agric. Formosa, Vol. 3, p. 89, Pl. 8, fig. 1.

ESTAMPADOR, 1937, Philipp. Journ. Sci., Vol. 62, p. 495.

Yoshida, 1941, Bull. Fisher. Exper. Sta. Tyosen, No. 7, p. 33, text-fig. 15, Pl. 9, fig. 1.

Phyllosoma Guerinii

DE HAAN, 1849, Fauna Japon. Crust., p. 226, Pl. 50, fig. 6.

Phyllosoma utivaebi

Toкioka, 1954, Publ. Seto Mar. Biol. Lab., Vol. 3, p. 362, text-figs. 14-15, Pls. 41-43.

Tokioka \& Harada, 1963, Publ. Seto Mar. Biol. Lab., Vol. 11, p. 425, figs. 1-4.

non Ibacus ciliatus

Utinomi, 1956, Coloured Illustr. Sea Shore Anim. Japan, 1st ed., Pl. 31, fig. 1.

\section{Materials examined:}

of $46 \mathrm{~mm}$, ơ $50 \mathrm{~mm}$, of $51 \mathrm{~mm}$, of $52 \mathrm{~mm}$, of $55 \mathrm{~mm}$, or $60 \mathrm{~mm}$, of $62 \mathrm{~mm}$, of $52 \mathrm{~mm}$, क $52 \mathrm{~mm}$. Off Minabe, Wakayama; approx. $100 \mathrm{~m}$; bottom sandy mud. November, 1961.

o $55 \mathrm{~mm}$. Off Minabe, Wakayama; approx. $100 \mathrm{~m}$; bottom sandy mud. January, 1962.

o $45 \mathrm{~mm}$, ơ $60 \mathrm{~mm}$, $\& 47 \mathrm{~mm}$, \& $53 \mathrm{~mm}$, \& $57 \mathrm{~mm}$. Off Minabe, Wakayama ; approx. $100 \mathrm{~m}$; bottom sandy mud. 19 March, 1964.

Also the specimens in the Rijksmuseum van Natuurlijke Historie, Leiden, from Japan and Hainan, in the Museum of the Academy of Natural Sciences, Philadelphia, from China, in the U. S. National Museum, Washington, D. C., from Japan, China, Philippines and Mindanao, in the British Museum (Natural 
History), London, from Japan, and in the Australian Museum, Sydney, from Japan, were compared.

\section{Description:}

The animal, when alive, is generally toned with reddish pink.

The carapace appears rather round in dorsal view, and is widest at the level of the 2 nd or 3 rd posterolateral tooth. The average ratio of width to length of the carapace is $2.11 \pm 0.07$, maximum 2.16 and minimum 1.94 . The protuberances on the median carina are not distinct. The orbit shows a narrow posterior incision without an intercalated tubercle. The anterolateral angle of the orbit terminates into a simple narrow tooth. The posterolateral lobe of the carapace does not cover the 1st abdominal pleuron when the animal is fully extended. The anterolateral tooth of the carapace (i.e. the tooth on the lateral margin of the carapace anterior to the cervical incision) is furnished with 2 to 5 accessory teeth on its lateral margin. The posterolateral teeth of the carapace number 11 , rarely 10 or 12 .

The thoracic sternum bears protuberances at the bases of pereiopods, which are rather sharply pointed, particularly in younger specimens. A blunt protuberance is distinguishable at the middle of its posterior margin in both sexes.

The epistome bears a ridge-like process on the ventral surface and 2 teeth on the anterior margin. The latters point anteriorly and slightly outwards; their inner margins in most cases are provided with minute teeth.

The median carinae on the abdominal terga are distinct on the abdominal segments II-V. The abdominal pleura are rather narrow and project outwards. The posterior margin of the 5th abdominal tergum and pleuron is furnished with small sharp teeth.

The anterior end of 3rd basal segment of the 1st antenna sometimes exceeds the anterior tip of the 2 nd antenna and sometimes not. The terminal segment of 2nd antenna is much broader and the ratio of width to length is from 1.6 to 2.1 , being generally larger in younger specimens. This segment is armed with 10 teeth on its anterior margin, and seldom with more or less.

The gnathal lobe of the mandible terminates into 3 strong spinous processes, the tips of which are of brown colour. The inner margin of the ischiomerus of the 2nd maxilliped is straight. The flagellum of the exopod of the 2nd maxilliped is distinctly subdivided. The 3rd maxilliped carries rows of spines on the inner and outer margins of the merus and on the outer margin of the basal segment of the exopod. The inner margin of its ischium is fringed with a row of spinous processes, but its outer margin is nearly straight. The merus of the 3rd maxilliped is not subdivided.

The 5th pereiopod forms a complete subchela in the female and an incomplete one in the male. 


\section{Occurrence:}

Ibacus ciliatus is known to occur in the waters of southern and western Japan (Yokoya, 1933 ; Utinomi and Harada, 1958). Nevertheless, few reports have dealt with this species in the Japanese waters, and little is known of its population, its larval life and ecology. Recently, Nishimura and Yamazaki (1961) reported that a couple of adult specimens of this species were fished off Niigata, far up northward along the Japan Sea coast of Honshu. On the other hand, we received from Mr. C. K. Ko a photograph of a single large
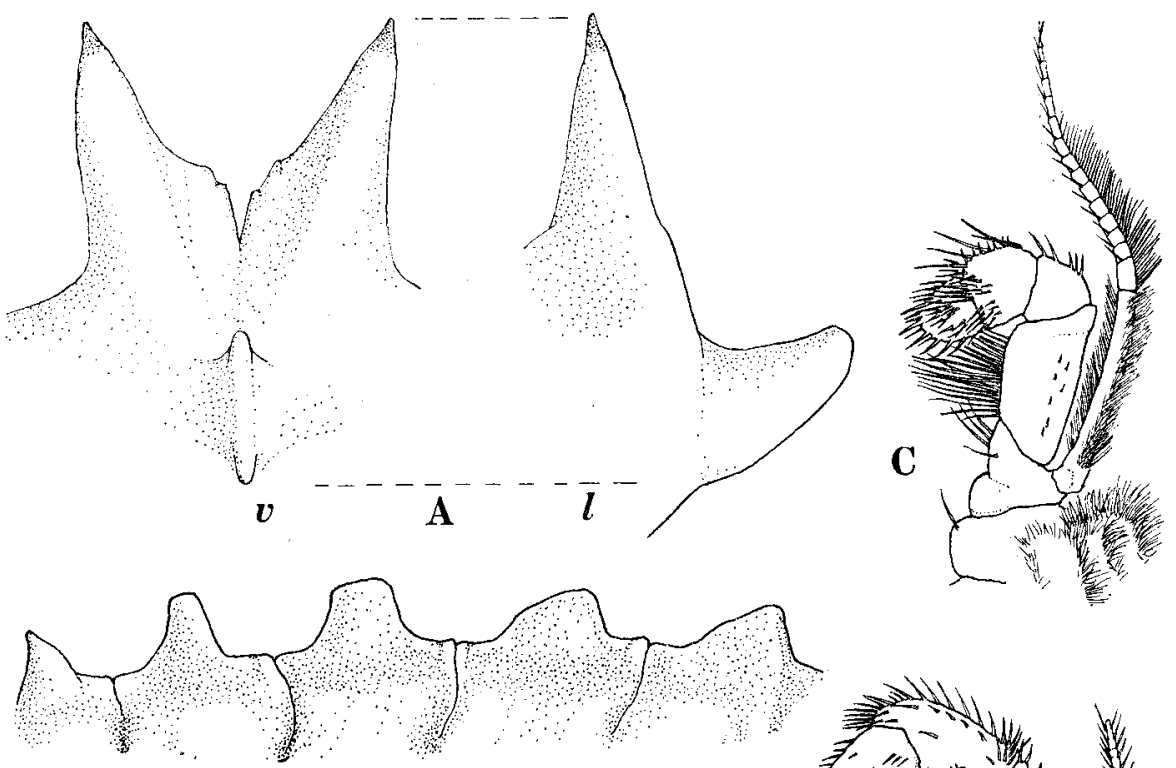

$\mathbf{F}$
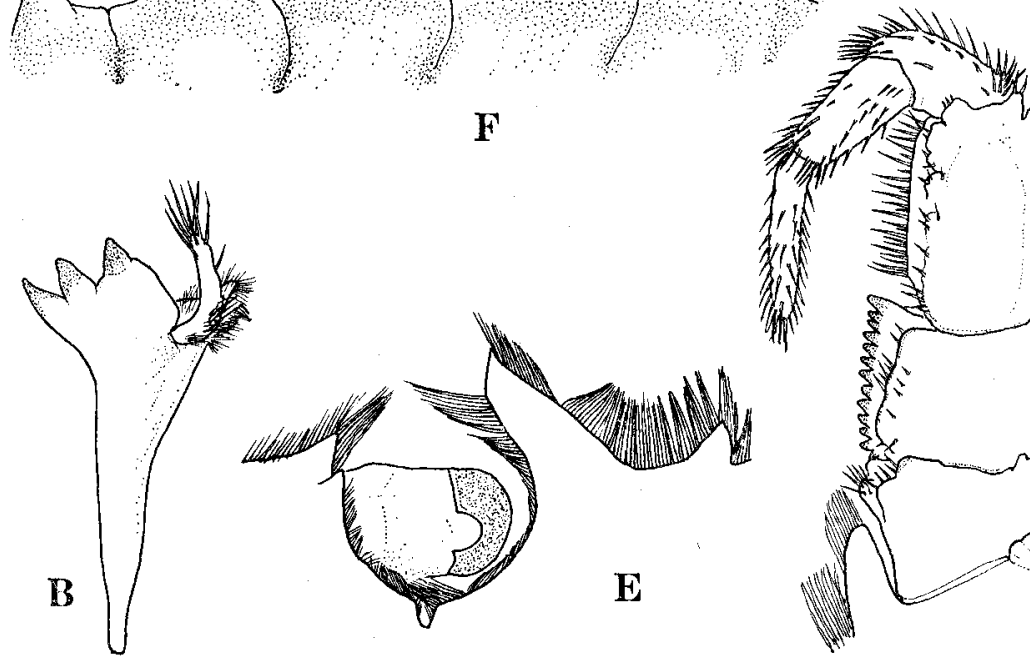

$\mathbf{E}$

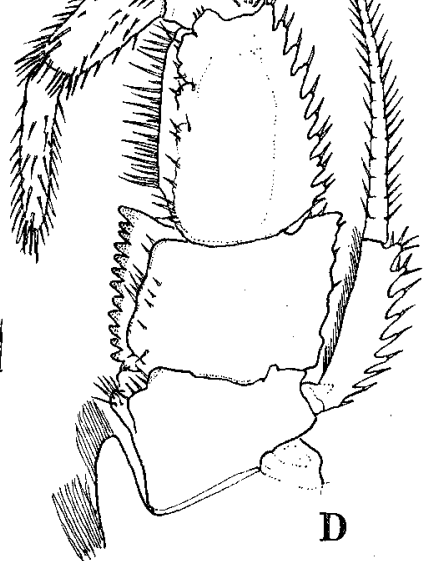

Text-fig. 2. Ibacus ciliatus (von SiEBoLD). Male, c. $1.55 \mathrm{~mm}$, from off Minabe. A, spines of epistome : $v$, ventral view, $l$, lateral view; $\mathrm{B}$, left mandible; $\mathrm{C}$, left 2 nd maxilliped; $D$, left 3rd maxilliped; $E$, right orbit; $F$, left ridges on thoracic sternum, lateral view. (A: $\times 4.5, \mathrm{~B}-\mathrm{F}: \times 3)$ 
specimen, nearly $100 \mathrm{~mm}$ in carapace length, which was caught by gill-nets in August, 1962, and this confirms the occurrence of this species off Hanrin, Cheju Island at the entrance of the Korea Strait. However, as far as we know, no records of its collection have been reported from the inbetween coastal waters of north-western Honshu, and it is not yet clear whether it is reproducing in the Japan Sea. Probably, the range of distribution of Ibacus ciliatus covers the whole of the southern and western Japanese waters, as well as further southern waters to Hainan and Mindanao, but it seldom penetrates into the Japan Sea, perhaps through transport by the dominant warm Tsushima current during its long pelagic larval life.

Ovigerous females are found from December to March in the catches off Minabe, and also appear in the aquarium until June.

\section{Ibacus novemdentatus GiBBES}

\section{(Japanese name: Ohba-utiwaebi)}

(Text-fig. 3 ; Plate VII, figs. 1-2)

Ibachus (sic) novemdentatus

Gibbes, 1850, Proc. Amer. Assoc. Adv. Sci., Vol. 3, p. 193.

Ibacus novemdentatus

Dan., 1852, Proc. Acad. Nat. Sci. Philad, 1852, p. 14.

Stimpson, 1860, Proc. Acad. Nat. Sci. Philad., 1860, p. 23.

GeE, 1925, Lingnaam Agric. Rev., Vol. 3, p. 159.

Ibacus ciliatus

Utinomi, 1956, Coloured Illustr. Sea Shore Anim. Japan, 1st ed., Pl. 31, fig. 1.

Ibacus incisus

KuBo, 1960, Encycl. Zool. Illustr. Colours, Vol. 4, p. 98.

Ibacus peronii

TokIOKA \& Harada, 1964, Publ. Seto Mar. Biol. Lab., Vol. 11, p. 433.

Utinomi, 1964, Coloured Illustr. Sea Shore Anim. Japan, rev. ed., p. 62, P1. 31, fig. 1.

\section{Materials examined:}

\& $58 \mathrm{~mm}$. Off Minabe, Wakayama; approx. $100 \mathrm{~m}$; bottom sandy mud. Early 1951.

\& $69 \mathrm{~mm}$. Off Minabe, Wakayama ; approx. $100 \mathrm{~m}$; bottom sandy mud. January, 1962.

\$ $53 \mathrm{~mm}$, \& $53 \mathrm{~mm}$. Off Masuda, Shimane; approx. $70 \mathrm{~m}$; bottom muddy fine sand. 13 November, 1962.

s $49 \mathrm{~mm}$, ㅇ $56 \mathrm{~mm}$, ㅇ $68 \mathrm{~mm}$. Off Minabe, Wakayama ; approx. $100 \mathrm{~m}$; bottom sandy mud. Early 1963.

\$ $51 \mathrm{~mm}$, \& $59 \mathrm{~mm}$. Off Kamaye, Ohita; depth and bottom unknown. August, 1964.

$\$ 50 \mathrm{~mm}$, क $59 \mathrm{~mm}$. Off Hachinosu-bana, Uwajima, Ehime; approx. 40-60 m; bottom mud. 27 November, 1964 .

Also the specimens in the Rijksmuseum van Natuurlijke Historie, Leiden, from Hongkong, in the Museum of the Academy of Natural Sciences, Philadelphia, from China, in the U.S. National Museum, Washington, D. C., from 
Formosa and Japan, and in the British Museum (Natural History), London, from off the mouth of Umvati River, East Africa, were compared.

\section{Description :}

Live specimens are pale yellowish orange with scattered red stipples.

The carapace is rather flat and almost square in dorsal view, and it is widest at the level of the anterolateral or the 1st posterolateral tooth. The average ratio of width to length of the carapace is $1.99 \pm 0.17$, ranging from 1.93 to 2.14 . The median carina on the carapace bears 4 distinct protuberances on its anterior half. The orbit has an small square incision on its posterior margin, which is without a trace of an intercalated tubercle. The tooth at the anterolateral angle of the orbit is furnished with 1 to 5 accessory teeth on its anterior margin. The posterolateral lobe of the carapace overlies over the 1st abdominal pleuron even when the animal is fully extended. The anterolateral tooth of the carapace is simple. The cervical incision is deep and straight. The posterolateral teeth of the carapace number 7 and rarely 8 or 9 . On the anterior margin of the carapace are 9 to 12 small teeth.

The ventral ridge-like projections near the lateral margins of the thoracic sternum are rather gently and shallowly cut into protuberances corresponding to the thoracic segments. There is no trace of the median protuberance on the posterior margin of the thoracic sternum.

The epistome is armed on its ventral surface with 3 sharp teeth: the 2 anterior directing forwards and the single posterior tooth directing ventrally. These 3 teeth are in most cases simple and are occasionally furnished with accessory teeth, particularly the posterior one.

The median carinae on the abdominal terga are distinct on the abdominal segments II-V. The abdominal pleura are rather broader than in I. ciliatus. The teeth on the posterior margin of the 5 th abdominal tergum and pleuron are rather blunt.

The anterior end of the 3rd basal segment of the 1st antenna does not exceed the anterior tip of the 2nd antenna. The ratio of the segments of the peduncle of the 1 st antenna is nearly $1: 1: 1$. The terminal segment of 2nd antenna is near oval, the ratio of width to length ranging from 1.40 to 1.52 with an average of 1.46 . The anterior margin of the terminal segment of the 2nd antenna is armed with 6 to 7 teeth. The 2nd basal segment of the 2nd antenna bears 6 to 10 small teeth on its anterior margin and 5 to 7 large teeth on its lateral margin.

The gnathal lobe of the mandible terminates into a row of small teeth and an anterior large tooth. A row of spines is present on its inner ventral surface. The inner margin of the ischiomerus of the 2nd mixilliped is convex. The flagellum of the exopod of the 2nd maxilliped is faintly subdivided. The 3rd maxilliped is armed with rows of spinous teeth on the 
outer margin of the merus, on the inner and outer margins of the ischium, and on the outer margin of the basal segment of the exopod. The ventral surface of the merus is strongly convex and is subdivided into 9 septa by incomplete furrows in its inner part, but does not form a spherical knob at its distal end as is seen in $I$. verdi.

The 5th pereiopod forms a complete subchela in the female, but does not in the male.

Ibacus novemdentatus is a species which so far has been little understood and has often been confused with $I$. peronii. Only a direct comparison of material of both forms brought to light that they represented distinct species. The main differences between these two species are the following:

1. In $I$. novemdentatus the posterior branchial carinae of the carapace (i.e. the branchial carinae behind the cervical groove) are straight or only slightly convex, lying in one line with the anterior branchial carinae. In $I$. peronii the posterior branchial carinae are remarkably convex with the convex side turned outwards, they do lie in one line with the anterior branchial carinae.

2. The posterior incision in the orbit in $I$. novemdentatus is square without a trace of an intercalated tubercle, while such a tubercle is present in I. peronii.

3. In I. novemdentatus the posterolateral teeth of the carapace (i.e. the teeth on the lateral margin of the carapace behind the cervical incision) number 8 , or more rarely 7 , while in $I$. peronii there are 6 or 7 , seldom 8 of such teeth.

4. The three anterior teeth of the epistome in $I$. peronii all are directed ventrally, being quite parallel. In I. novemdentatus only the single posterior of these teeth is directed ventrally, the two anterior point forwards.

Ibacus novemdentatus was originally reported by GibBes (1850) from an unknown type-locality, the first definite locality given for the species was Hongkong, whence it was mentioned by Stimpson (1860). Later, under the name of $I$. peronii, the species has also been reported from East and Southeast Africa, a specimen of which is deposited in the British Museum (Natural History), London, U. K. The U. S. National Museum at Washington, D. C., U. S. A., possesses two specimens of this species, one from the Kururi district, Tokaido, of Japan, collected by Mr. F. Sakamoto in March, 1893, and the other from Chilung, Formosa, collected by Dr. M. Orshima on 18 January, 1916. It is not, however, certain where this "Kururi district" precisely is. Furthermore, from it locality and date of collection, we presume that the latter specimen might be identical to that reported by MAKI and Tsuchiy A (1923), some of whose materials were said to have been sent for identification 
to Dr. M. J. Rathbun. Through the kindness of Dr. A. J. Bruce of the Fisheries Research Station at Hongkong, the Rijksmuseum van Natuurlijke Historie recently received three specimens from southeast of Hongkong.

Ibacus peronii so far is only known with certainty from southwest, south and southeast Australia. Records of this species from south Africa, the Philippines and Chile need confirmation.

Occurrence :

Ibacus novemdentatus, the newly recognized member of the Japanese continental shelf fauna, judging from its occurrence in trawl catches, appears to be unexpectedly common and evidently reproduces here, as ovigerous females have been found. According to the fragmental records of collection by HARADA, who had not at that time clearly discriminated between the two species of Ibacus, I. novemdentatus has been fished occasionally by trawling off Minabe, Kii Strait, since 1956. More precise records have been provided by Mr. Ch. Araga of the Seto Marine Biological Laboratory, who found five specimens of $I$. novemdentatus among 19 specimens of Ibacus that were trawled off Minabe and were supplied to the Aquarium of the Laboratory during the period from April 1962 to March 1963. However, a sample trawled off Minabe on 17 March, 1964, was composed of $81 \mathrm{I}$. ciliatus and $1 \mathrm{I}$. novemdentatus. Perhaps the habitats of these two species are slightly different, which is also the impression of some fishermen, although both species inhabit the level bottom of the continental shelf.

The presence of two types of Ibacus has been, though only vaguely, noticed by fishermen on the southern coast of Shikoku Island (personal information from Mr. C. K. Ko). A number of Ibacus from off Kamaye, Ohita, supplied to the Miyajima Aquarium in August, 1964, are all identified as I. novemdentatus by HARADA. Further, all 3 specimens of Ibacus caught by a trawler off Masuda, Shimane, on 13 November, 1962, are I. novemdentatus. According to the personal information from Mr. K. NAKANo of Tamagawa, Yamaguchi, who collected these specimens, the species (called "kejirami-gani" locally) is frequently caught also by bottom long-lines between Tsushima Islands and off Masuda, $60-130 \mathrm{~m}$ in depth. These are taken as a proof that the range of Ibacus novemdentatus extends into the western Japan Sea.

Thus, considering these records together, $I$. novemdentatus is widely distributed over the western Japanese waters, including the western part of the Japan Sea. However, it must be left for further investigation to ascertain how far the range of $I$. novemdentatus extends northwards along the Pacific and the Japan Sea coast of Japan. There is no doubt that $I$. novemdentatus has wider geographical distribution than I. ciliatus. Perhaps we may consider that I. ciliatus, although, contrary to the notion by BALss (1924) or EkMAN (1953), it is not exclusively characteristic to the subtropical Japan, is a 
specialized form also in its morphology and is restricted to the western Pacific region, in contrast to the less specialized $I$. peronii group (containing I. peronii and $I$. novemdentatus).

The breeding season of $I$. novemdentatus is in spring, as ovigerous females are found in the March catches.
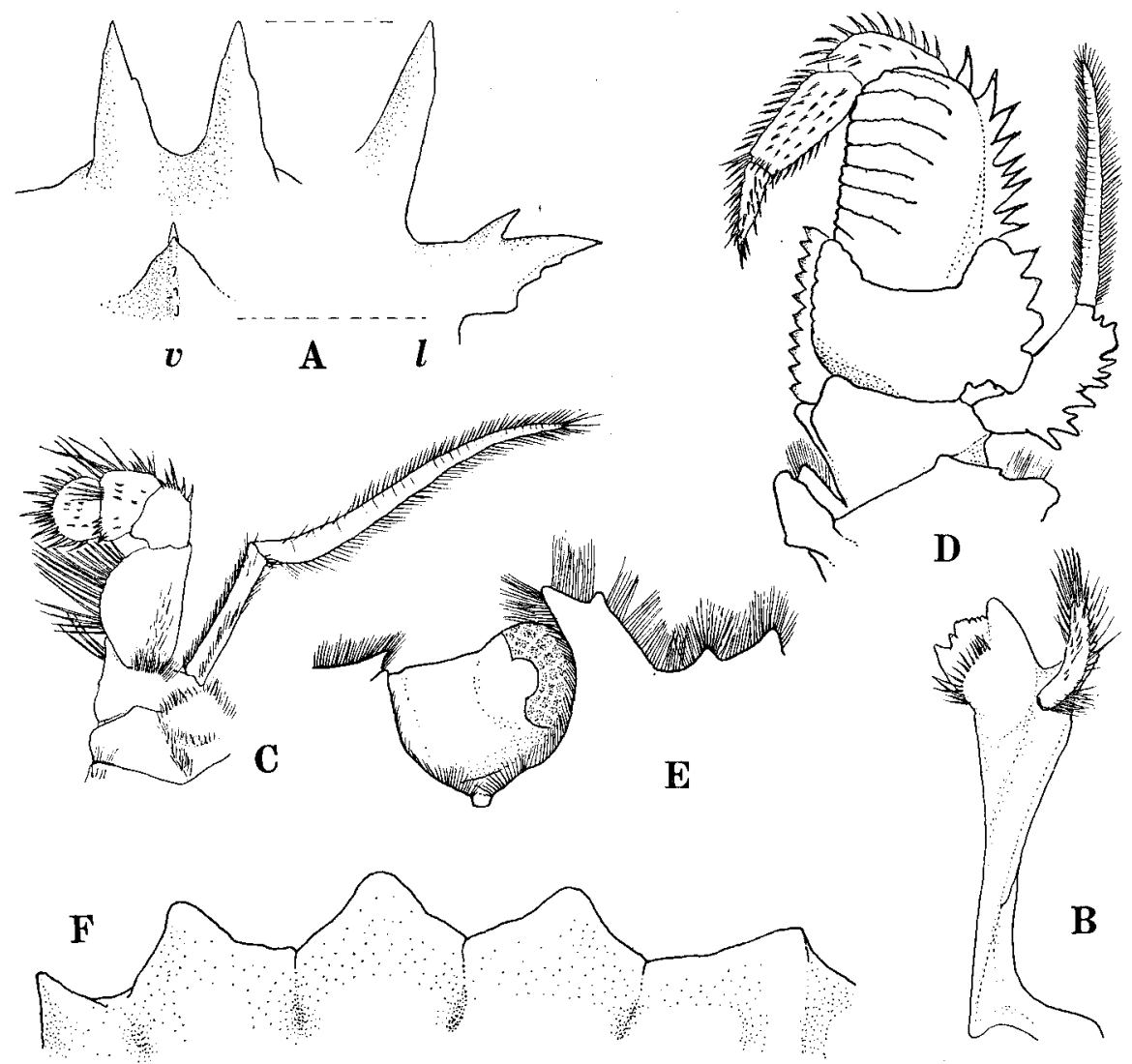

Text-fig. 3. Ibacus novemdentatus Gibbes. Male, c. $1.53 \mathrm{~mm}$, from off Masuda. A, spines of epistome: $v$, ventral view, $l$, lateral view; $\mathrm{B}$, left mandible ; $\mathrm{C}$, left 2nd maxilliped; D, left 3rd maxilliped; E, right orbit; F, left ridges on thoracic sternum, lateral view. (A: $\times 4.5, \mathrm{~B}-\mathrm{F}: \times 3)$

\section{Sommario}

La conoscenze sulla distribuzione delle specie giaponèsi del genere Ibacus, anche per i loro caratteri morfologici, non sono che piccoli prima di oggi. Il presente lavoro ha lo scopo di chiarire i punti dubbiosi della determinazione specifica di questo genere vivente nelle regioni vicine di Giappone.

Due specie si trovano, Ibacus ciliatus (vON SiEBOLD) e Ibacus novemdentatus 
Gibbes; giu abbiamo detto la descrizione dei materiali pescati di questi due specie. L'Ibacus novemdentatus che il GibBes (1850) trovò per primo dal luogo sconosciuto e di cui il Kuвo (1960) recentemente fece una breve notizia come l'Ibacus incisus, è così comune nei mari di sud-Giappone e ancora nella parte occidentale del Mar Giappone a circa 100 metri di profondità.

L'Ibacus novemdentatus si differenzia nettamente dall' Ibacus ciliatus, ma rassomiglia più alle altre specie affini, Ibacus peronii e Ibacus incisus, per caratteristiche proprie, che si possono riassumere per le più appariscenti: per numero delle spine posterolaterale del scudo cefalotoracico, nella disposizione delle carene posteriori branchiali sullo scudo cefalotoracico, nella disposizione di due grandi spine apicali e una spina molto sviluppata solamente ventralemente sulla epistome, e nella forma dei massillipedi del terzo paio col quarto articolo suddiviso.

\section{REFERENCES}

Balss, H. 1914. Ostasiatische Decapoden. II. Die Natantia und Reptantia. Beiträge z. Naturgesch. Ostaciens, Abh. Bayer. Akad. Wiss., Suppl. Vol. 2, Pt. 10, pp. 1-101, text-figs. 1-50, P1. 1.

1924. Ostasiatische Decapoden. V. Die Oxyrhynchen und Schlussteil. (Geographische Übersicht der Decapoden Japans.) Arch. f. Naturgesch., 90 Jahrg., Abt. A, 5 Heft, pp. 20-84.

Doflern, F. 1902. Ostasiatische Dekapoden. Abh. Bayer. Akad. Wiss., Vol. 21, pp. 613-670, text-figs. A-D, Pls. 1-6.

EKMAN, S. 1953. Zoogeography of the Sea. Sidgwick \& Jackson, London. xiv +417 pp.

Estampador, E. P. 1937. A check list of Philippine Crustacean Decapods. Philip. Journ. Sci., Vol. 62, pp. 465-559.

GIBbEs, L. R. 1850. On the carcinological collections of the cabinets of natural history in the United States. With an enumeration of the species contained therein, and descriptions of new species. Proc. Amer. Ass. Adv. Sci., Vol. 3, pp. 165-201.

HAAN, W. DE. 1833-50. Crustacea. In : P. F. DE SiEBold's Fauna Japonica, pp. 1-244, Pls. $1-55+A-Q$.

HARADA, E. 1958. Notes on the naupliosoma and newly hatched phyllosoma of Ibacus ciliatus (von Siebold). Publ. Seto Mar. Biol. Lab., Vol. 7, pp. 173-180, Pls. 9-11.

Holthuis, L. B. 1947. Biological results of the Snellius Expedition. XIV. The Decapoda Macrura of the Snellius Expedition. 1. The Stenopodidae, Nephropsidae, Scyllaridae and Palinuridae. Temminckia, Vol. 7, pp. 1-178, Pls. 1-11.

MAKI, M. and TsuchiyA, H. 1923. Illustrated reports of Crustacea Decapoda from Formosa. Rep. Dept. Agric. Formosa, Vol. 3, pp. 1-215+4, Pls. 1-24. (In Japanese)

Nishimura, S. and Yamazaki, N. 1961. Records of occurrence of a scyllarid lobster, Ibacus ciliatus (von Siebold) off Niigata Prefecture. Coll. \& Breed., Vol. 23, pp. 281-282. (In Japanese)

Ortmann, A. 1891. Die Decapoden-Krebse des Strassburger Museums, mit besonderer Berücksichtigung der von Herrn Dr. Döderlein bei Japan und den Liu-Kiu-Inseln gesammelten und z. Z. im Strassburger Museum aufbewahrten Formen. III Theil. Die Abtheilungen der Reptantia Boas: Homaridea, Loricata und Thalassinidea. Zool. Jahrb., Abt. Syst., Vol. 6, pp. 1-58.

Stebbing, T. R. R. 1893. A History of Crustacea. Recent Malacostraca. Internat. Sci. Ser., Vol. 74, xvii +466 pp. Kegan Paul, Trench, Trübner \& Co., London.

STIMPSON, W. 1860. Prodromus descriptionis animalium evertebratorum, quae in Expeditione 
ad Oceanum Pacificum Septentrionalem, a Republica Federata missa, Cadwaladaro Ringgold et Johanne Rodgers Ducibus, observavit et descripsit. Pars VIII. Crustacea Macrura. Proc. Acad. Nat. Sci. Philadelphia, Vol, 12, pp. 91-116.

Tokioka, T. and Harada, E. 1964. Further notes on Phyllosoma utivaebi Tokioka. Publ. Seto Mar. Biol. Lab., Vol. 11, pp. 425-434.

UTINOMt, H. and HARAdA, E. 1958. A. list of bottom animals collected by a trawler "Kaiunmaru" off the southwest coast of Kii Peninsula. Ibid., Vol. 6, pp. 385 395.

YOKOYA, Y. 1933. On the distribution of decapod crustaceans inhabiting the continental shelf around Japan, chiefly based upon the materials collected by s. s. Sôyo-maru, during the year 1923-1930. Journ. Coll. Agric. Tokyo Imp. Univ., Vol. 12, pp. 1-226.

\section{EXPLANATION OF PLATE VII}

Figs. 1-2. Ibacus novemdentatus, female, carapace length $69 \mathrm{~mm}$. Off Minabe, Wakayama. January, 1962.

1. Dorsal view.

2. Ventral view.

Figs. 3-4. Ibacus ciliatus, male, carapace length $55 \mathrm{~mm}$. Off Minabe, Wakayama. January, 1962.

3. Dorsal view.
4. Ventral view. 

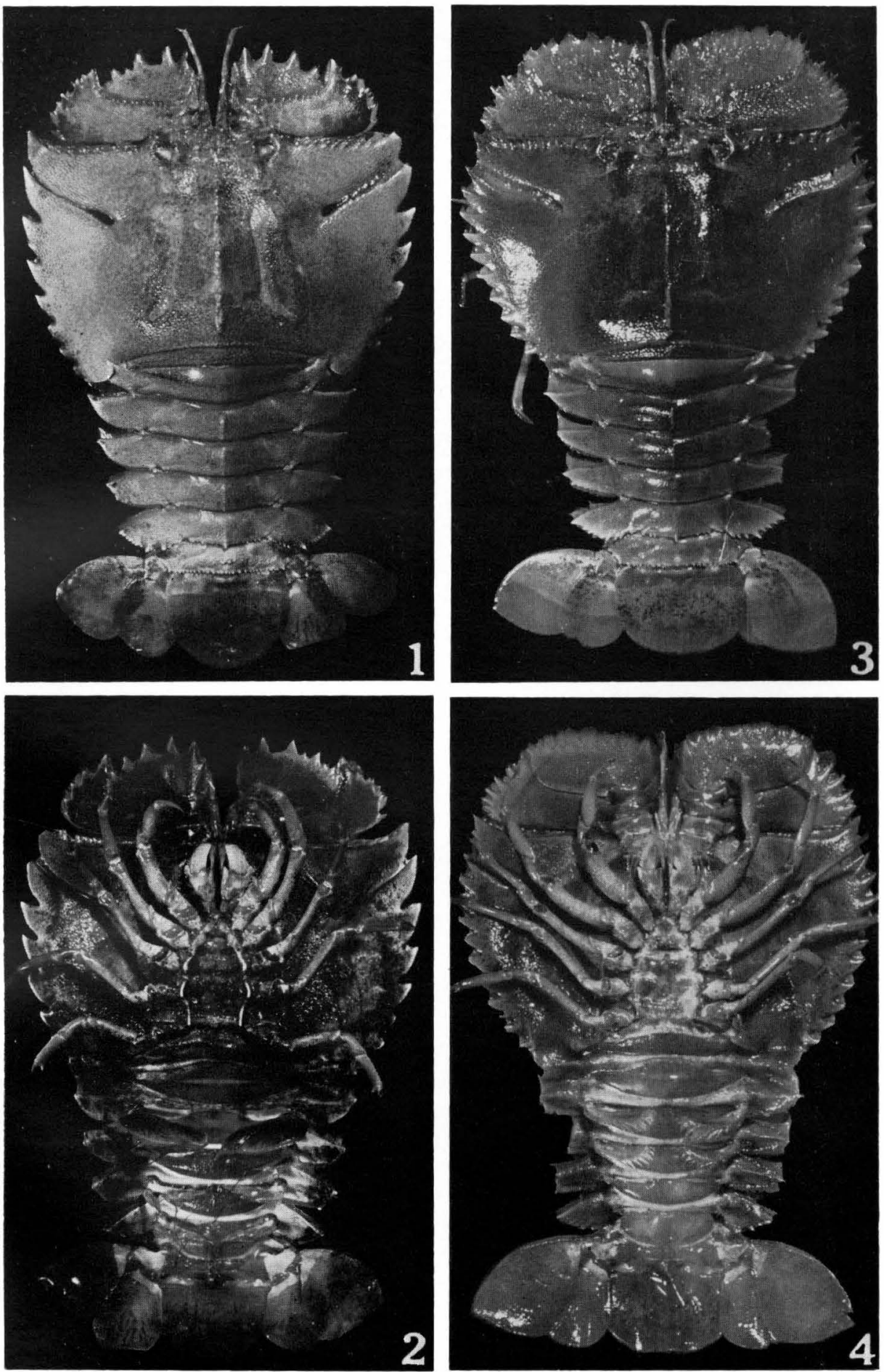

E. Harada and L. B. Holthuis: Two Species of Ibacus from Japan. 